\title{
Preserving architectural heritage in historical cities: study of the architectural heritage with the end of the nineteenth century and the beginning of the twentieth century in Alexandria, Egypt
}

\author{
K. Heba \\ Department of Architecture, Al-Azhar University, Egypt
}

\begin{abstract}
Alexandria has been influenced by resident foreigners descended from various nationals who spread all over the city by the end of the nineteenth century. That gave Alexandria a unique pattern of architecture that included a blend of several classical European patterns, with their diversity and richness. These unique patterns have lasted until the first years of the twentieth century.

Alexandria has been altered with the political, economical and social conversion during the second half of the 20th century. Alteration has occurred due to other causes as well. To mention, the migration of the foreign nationals from the city, while reversing rural migration toward the city, along with a highdensity growing population. This led to seriously different and controversial cultural and intellectual points of view. The second half of the 20th century has witnessed a process of destruction to this distinctive architectural heritage. This happened for the reason of an overwhelming spread of concrete buildings and towers that lacked the aesthetic architectural sense.

The purpose of this paper is to highlight the value and the potentials of this architectural heritage. Also, to underline the successive individual attempts that have been taken into practice for preserving this heritage in Alexandria. In addition, this paper will attempt to reach appropriate guidelines to guarantee that preservation processes will compromise only by reserving the rights of private properties within an unbiased attitude towards the owners of such heritage. This
\end{abstract}


will occur through searching into other countries' previous experience and efforts in preservation processes for such valuable buildings.

Keywords: preserving, Alexandria, heritage, historical cities.

\section{Alexandria, its establishment and development- a foreword and introduction}

After the Arabic Islamic conquest of Egypt in 641 A.D, Alexandria had begun to lose focus and importance as a main urban city. A new capital was established and the harbor, then, was transferred to Rosetta, causing Alexandria to start suffering from neglect and oblivion.

This situation had continued through all the successive Arabic Islamic ages in Egypt, until the French Campaign in 1789, while Alexandria was in a poor phase and its population was then around 15 thousand, while the city was actually living an era of decline and neglect.

Mohamed Aly took the leadership in 1805, when he started carrying out his revolutionary civilization project by establishing a modern state (Al-Rafey [1]) in which his view of Alexandria was totally different to all his predecessors, where he was concerned of Alexandria and its urban structure. That caused a great progress to the city, which attracted foreigners to settle down in Alexandria, where they formed large different communities of various nationalities.

In 1845, Mohamed Aly built himself the Ras El-Tin Palace (Awad [2]). Then, because of the growing foreign communities in the city in this period, they started searching for ways of developing and refining this city. These efforts started by forming a Municipal Council in 1834, which became the nucleus of the first municipal council in Egypt (Shalaby [3]). The main concern of this Council was to improve the city image, its urban planning. Mohamed Aly's successors established the first railway line between Alexandria and Cairo (1851-1856), which also contributed to the growing importance of Alexandria.

Under Ismail Pasha's rule in 1863, the urban structure of Alexandria flourished, where he planned new roads and new districts, such as (Al-Ramleh district), which was connected to older western districts by a suburban railroad. Ismail had also developed the Consuls' Square (French Gardens Square); he built several exquisite houses and buildings all around this square as residences for the foreign Consuls, where the square's name gained its name (Awad [2]). All these improvements had increased population to 212 thousand at that time (Heba [4]).

Because of this growing numbers of foreigners in Alexandria, the city witnessed a large commercial flourish during the last quarter of the 19th century. This economic progress had also initiated another development in the Municipal Council, by forming what was called "Exporters' Committee" (1869-1879), that followed by the first real and formal Municipal Council 1890 (Shalaby [3]) to supervise officially the execution of all municipal developing projects.

With the early years of the 20th century, Alexandria started another new revival. Despite the situation of Egypt being under British occupation supported urban improvements of the city, again, the number of foreigners increased in the 
city, and the urban and construction activities flourished. That made Alexandria a unique model of a European city, except for the older districts of west Alexandria, which was crowded by the national classes of the population, who kept their inherited plans of the old Arabic Islamic traditional city (Heba [4]).

By the end of the 19th century and the beginning of the 20th century, the mixing and interacting process of this mixture of western cultures, especially from Southern Europe, along with the genuine culture of Alexandria. The city had become one of the most glorious cities of the whole east, and had - worthilywon the name of "The Bride of the Mediterranean Sea". Alexandria had seen a unique construction wave of buildings of great and priceless architecture value that included characteristics of the classical European architecture.

This environment had continued to exist also during the first half of the 20th century, within an architectural competition for the sake of beauty and perfection (fig. 1).
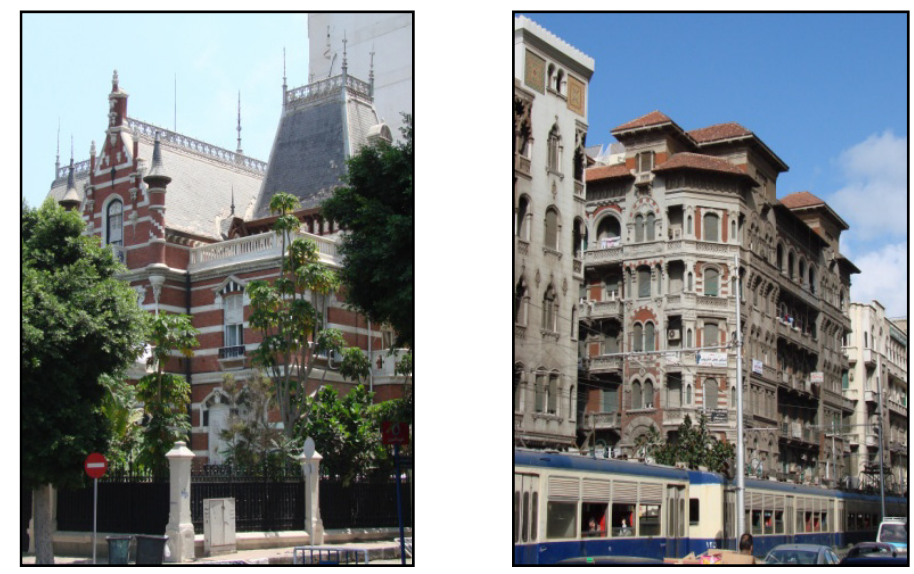

Figure 1: $\quad$ Examples from the architectural heritage of Alexandria.

\section{Political and social changes by the second half of the $20^{\text {th }}$ century, and its impact on Alexandria architectural heritage}

With the rise of the Revolution of the 23 July 1952, which the rising national feeling tide was its actual supportive base in confronting the British occupation, which a few years later was bound to leave Egypt, yet, still the British troops came back again in another form during Suez war in 1956. This has persuaded a large number of the settled foreigners to leave Egypt to their home countries. On the other hand, Alexandria has witnessed at the same time a large unplanned internal migration of huge numbers from the rural areas, looking for better employment and better life that were provided by the industrialization progress that started after being restrained for decades by the British occupation. 
This unplanned and unexpected migration flow to Alexandria has caused a radical change in the population characteristics of the city, where large numbers of completely different mentalities, culturally and intellectually, started to invade the city, bearing new sharp materialistic concepts of life, devoid of any value for art, cultural and intellectual side of life. The city gradually became burdened with growing sectors of peasants, carrying over with them their own habits, language and life style that were quite unfamiliar to the city, and did not match the nature of a city with special patterns and culture like Alexandria (Heba [5]).

The first half of the 20th century has seen several masterpieces created by foreign architects who came from different countries who have contributed to enriching Alexandria by adding more buildings that are exquisite. Which reflected so much of the architectural unique patterns, and would remarkably point out their elevated artistic taste such as the famous French architect "August Pirier" and the Italian architect "Mario Rossi" and others.

Yet, by the second half of the century, as a result of the remarkable change in Alexandria population mix, a strong move has started to destroy and devastate those wonderful treasures of Alexandria. Amazingly, these moves were not met by any kind of serious resistance. Eventually, these attempts have vigorously increased during the late seventies until the end of the 20th century.

By the beginning of the 21 st century, these ferocious attacks were continued to escalate, more powerfully and more melodramatically for achieving more benefits without any respect to urban, cultural and aesthetic values. As well as disregarding, even the future economic values of those treasures of unique heritage would represent to the city if they could have spared and preserved for future generations that could never compensate such grotesque villas, residential buildings and palaces. Those rare works of art have actually made Alexandria, by the second half of the 20th century, look like an open live museum (Heba [5]).

\section{The recurrent attempts to preserve Alexandria's architectural heritage}

Lately some initiatives were undertaken by the local authorities against the will of some interested parties as follows:

\subsection{The comprehensive planning for Alexandria at 1984}

Throughout the social change period in Egypt during the sixties of the 20th century, the state being concerned and focusing on low-income classes, up to the Open Economy phase following the two wars of 1967 and 1973. No authority has ever paid any attention to the problem of preserving this unique heritage. Yet, with the relatively stable condition of political and military issues after signing a peace treaty with Israel, and by the early eighties of the 20th century, there was an attempt to draw up a comprehensive strategy for an urban revival, through an integral planning of Alexandria in 1984 (The comprehensive planning for Alexandria) (Zahran [6]), which showed interest to preserve this heritage, and this was the first formal reference to the importance of this cultural 
heritage, along with several major recommendations and proposals for a comprehensive planning of maintaining this preservation, as well as specifying the expected benefits of this preservation. This planning also has included - for the first time - a detailed list of the most important buildings, areas and monuments of historical and cultural values that should be taken care of preserved and maintained. In addition, the comprehensive planning has indicated that specialized committees must be formed for studying each singular case of those buildings and monuments separately concerning any request for change, modification, repair or demolition suggested for any of these items. However, this, unfortunately, has never happened then, and still to this moment (Heba [5])

Then, as a supporting factor for the above issue of preserving this unique heritage, a resolution for detailed the comprehensive planning of Alexandria was issued from Alexandria's governor (Resolution No. 288 of 1992), (Haidar [7]) of which the First Chapter has stated the requirements of building in historical areas which should guarantee the serious preservation of these spots. This Chapter has also included several other points, mainly the following.

1. Forming a Supreme Committee for Arts and Architecture, to study and review all cases of such buildings to be developed, maintained or restore.

2. Studying an exemption to be approved for owners of these above-mentioned buildings from paying some charges and taxes due, as a contribution by the government in the maintenance cost of such buildings, and to encourage these owners to maintain and preserve these buildings. This above mentioned Committee would also prepare the necessary legislation to carry out these steps.

3. Studying a choice of some of those buildings to be used as exquisite show rooms or temporary museums for displaying and exhibiting some rare monumental pieces and some Egyptian and international works of art (e.g. museums for currency notes and coins, historical costumes, postage stamps, jewelry, paintings and photographs, sculpture, culture and literature activities.. etc.). This should be organized in collaboration with the firms and concerned authorities, in coordination with the owners of those buildings.

Therefore, the above-mentioned resolution has actually completed what was included in the recommendations of the comprehensive planning of Alexandria issued in 1984, to form together one integral unit, and this may be mainly caused by a full understanding of the local leadership, represented by Alexandria's governor of the importance and value of Alexandria heritage.

In fact, the same resolution No. 288 of 1992 has actually started to be carried out from 1993 until 1997 (Haidar [7]), and those buildings were spared from any damage. Yet, some greedy investors again persuaded some authorities, supported by some forms of public pressure, some contracting companies and the Syndicate of Engineers in Alexandria. They all shared in resisting and fighting against this resolution for their own personal interests, under a pretense that this resolution has caused a complete stop (a paralysis) to the contracting business in the city. Especially when they reviewed the rest of the resolution, which divided Alexandria into several zones, each, of which the resolution specified its new building requirements. That included maximum heights, building densities, and has set certain penalties and increased punishment on building demolition 
without prior official permits, and has totally prohibited building on land previously occupied by villas, palaces or buildings of value, if demolition was carried out without prior official permit.

\subsection{The coup on the operations of preserving the architectural heritage}

Then, with the change of the local leadership of Alexandria in 1997, and in one theatrical move to please the effective public opinion of business sector and interested parties, the new administration - right upon being assigned in July 1997 - started by canceling the resolution 288 of 1992 . To be substituted only by applying the General Building Law No.106 of 1976 (Haidar [7]) and its amendments. This caused a real devastating catastrophe to Alexandria within only a few months, as a large number of this heritage were lost and - as stated by some responsibly authorities at the Governorate itself - "actually caused a massacre of villas and palaces" (Rezk [8]). For example, the exact number of historical villas and palaces demolished during 90 days in 1997 were 102 villas and palaces. This number is located only in one district of Alexandria's six districts, (which includes Al-Ramleh suburb of the good old flourishing days).

This tragedy was the center of a great feeling of contempt and anger expressed by the academic and cultural community. This pushed an official reaction by the prime minister to issue (Martial Resolution No. 463 on 12 February 1998), prohibiting demolition of villas in any form and in all of Egypt, which supported the initiative move previously taken by the city in regards to the preservation process of this heritage. This Resolution made the Governorate start preparing new lists in 1998 for the buildings that should be preserved.

Yet, again, these lists were also violated, and a number of those buildings could not escape some swindling and cunningly planned tricks to overrule this Resolution. One of them was the building No. 410, Al-Horreya Avenue in Roushdy district. That was demolished by such incorrect means in October 2002, (fig. 2) which, again, has aroused the community of intellectuals in the city, and this proves that it seems that nothing would work to make those responsible at the Governorate feel the actual value of this rare heritage and its importance.

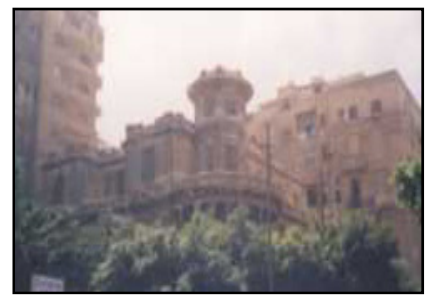

Figure 2: A rare photograph shows building No. 410, Al-Horreya Avenue, which was demolished illegally in October 2002.

Accordingly, the study will attempt, in its next part, to explain how advanced countries have handled such situation in dealing with heritage, and the other 
urban sides of the preservation process, taking into consideration - at the same time - the lawful rights of private property. Lastly, by the end, the study will review the proposals in this respect to preserve the unique architecture pattern of Alexandria, and hold to what currently remains of this valuable and unique heritage in that city.

\section{Experiences of some other countries in preserving their architectural valuable heritage}

The most important characteristics of urban civilized conduct is preserving the cultural resources of a country by cherishing, holding and maintaining the architectural heritage, and the urban settings of cities are considered as one of its main characteristics of their existence.

\subsection{Preserving of historical buildings}

One of the major requirements for applying and controlling such plan for preserving this heritage is to assign committee to become responsible for urban and architectural setting of a city, who must receive and review all details and drawings of new projects. Those should study, review and decide whether the drawings would fit the overall setting and pattern of the area and district, and would decide if the type, colors and materials would match with the architectural and urban local heritage. An alternative is to study the possibility of keeping the façade of some buildings and re-build it behind, (as in the case of Marriott Hotel in the Champs Elisée in Paris, [9], which became a witness to sincerity in preserving the architectural heritage of this great and famous road along without obstructing the construction of an international investment project).

Those cities would do their best on introducing their valuable cultural heritage, by pacing information next to the buildings (fig. 3), (in Paris, for example, a special attractive column was designed with an oval sign board to be placed in front of each of these valuable buildings, which includes its story and history in a summary of a few lines).
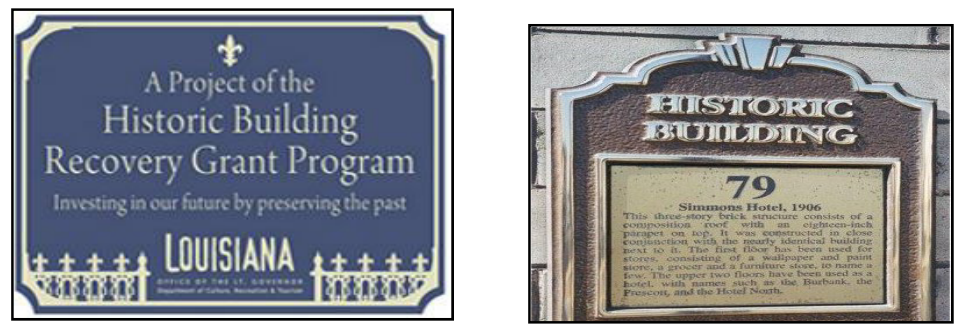

Figure 3: $\quad$ Examples of the historical and valuable buildings' signage.

For reaching such a level of refined cultural, technical and architectural attitudes that care for preserving their heritage, have special colleges which accepts graduates of architectural/engineering colleges who wish to specialize in 
city setting architecture and architectural restoration of buildings. For example, the "Ecole de Chaillot" in France [9], is a school dedicated to studying history and patterns of architecture, architecture of cities, laws and regulations governing them, and architecture of historical and monumental buildings. Such graduates enabled those countries to form remarkable crew of architects responsible for architectural setting of each district. In addition, they are responsible for restoration processes of monuments and historical buildings to guarantee preservation of the country's unique heritage, to avoid such neglect as the case with Alexandria architectural heritage.

\subsection{Other urban aspects of the preservation processes}

Urban aspects of the preservation processes and demolition restrictions of such buildings are not confined to traditional and cultural values (although this is what really concerns us in this study on Alexandria's architectural heritage). However, they also include several other architectural sides that should be raised for gaining maximum support by public opinion for adopting this heritage preservation process (Heba [5]). Since the establishment of Alexandria as a linear city, its roads and streets was limited and restricted - either in number or in streets' width - as those streets have no potential capacity for vertical increase to cope with the increasing density resulting from substituting villas and palaces by multi story buildings and towers. Therefore, does the growing pressure on different utilities such as sewage, electricity, water and other networks (despite the recent years' expansions). That made the city incapable of abolishing the city vertical expansion, and caused a lot of problems and bottlenecks in traffic and in all services that emerged lately on the surface.

All those problems represent, also, an increasing burden on the country's budget and act as extra load for solving these problems, instead of directing this extra cost towards development and modernization processes. In addition, this, in turn, would reveal the necessity to find some mechanism and a substitute radical solution for this dilemma that balance between the preservation process of the city urban overall fabric, its heritage and architectural identity on one side, with the population needs and increasing growth on the other side.

Such solution could possibly indicate, for example, expansion in building residential complexes around the mother city, transferring the overpopulation to the city outskirts - as the case of London in establishing new towns after the World War II for transferring the overpopulation from city center areas to settle behind the green belt around it (Haidar [7]).

\section{Heritage preservation and the private property rights}

Other than the urban and cultural considerations, the following suggestions are presented in order to maintain the individual property rights: 


\subsection{The conflict between private property and heritage preservation}

One of the main problems that face heritage preservation is the conflict between supporters of private property rights of landlords of those buildings, concerning their rights for a free hand in handling their property (regardless of urban and cultural considerations). Against supporters of the government's total grip of those buildings (regardless any individual considerations) who stick to preferring the society's welfare over the individual's rights. Those are mainly cultured, architects and academic community who were always the campaign leaders that defended this concept. However, this concept is not fair to those owners. Moreover, we have to admit that this judgment has never scored any positive result in favor of the preservation cause. In fact, it has negatively affected the preservation plans, as the materialistic side often mastered the urban issue. This has required a re-considering evaluation of this situation of adhering to preservation of this heritage without considering the issue of private property rights. Which would certainly achieve the aim of preserving these treasures, since the major obstacle in the course of a preservation process are actually investments. Since most of those buildings are owned by individuals, who must take a defensive stand for their rights to benefit from their own property. Considering the current scarcity of land and the growing of investments, which drove many of those owners to sell these unique properties to some contracting companies to be demolished later - either legally or otherwise - and to be substituted by residential towers (fig. 4).



Figure 4: Aghion family villa in Alexandria designed by the famous French architect (August Pirier) as an example for the valuable heritage buildings that need to be preserved.

Therefore, it is imperative to think of some other unconventional method for preserving these works of unique urban heritage, but taking into consideration the issue of private property rights and the cost of such a solution or settlement.

\subsection{Proposals for supporting maintenance and preservation of this heritage}

Despite the conflict between proprietors of those unique buildings to sell their property, yet, still, there are some few cases among them - which are considered exception to the rule - who refused such offers. In addition, although the government has confiscated a number of those valuable buildings after the 1952 Revolution, which were used for public services as schools, government 
authorities and others, yet there were some owners who preferred selling their villas and palaces to companies and organizations, to be re-used for whatever suits these new owners' activities. This type of conduct should be intervened by the government and other concerned firms for the sake of preserving this heritage. This intervention would go parallel to the application of laws and regulations that prohibit demolishing or modifying those buildings. This would be handled properly thorough a legislation that addresses newly-established investment companies, economic firms and banks to take such buildings as their administrative offices, and to guarantee their commitment of regular maintenance, and using them in the best proper way possible. This approach could be easily supported by an appropriate mechanism - through a legal procedure - to grant some facilities to these firms if they accept such an offer.

This solution could encourage the preservation of such buildings for almost no cost, save only a commitment to supervise and monitor the application of this agreement, through a high-caliber technical crew. The actual success of the previous examples of banks, organizations and other large firms would certainly stimulate those interested to join forces for supporting the noble aim of saving and preserving those valuable buildings, which - at the same time - supports the rights of proprietors of those buildings, and compensate them generously and properly in a decent civilized manner (fig. 5).
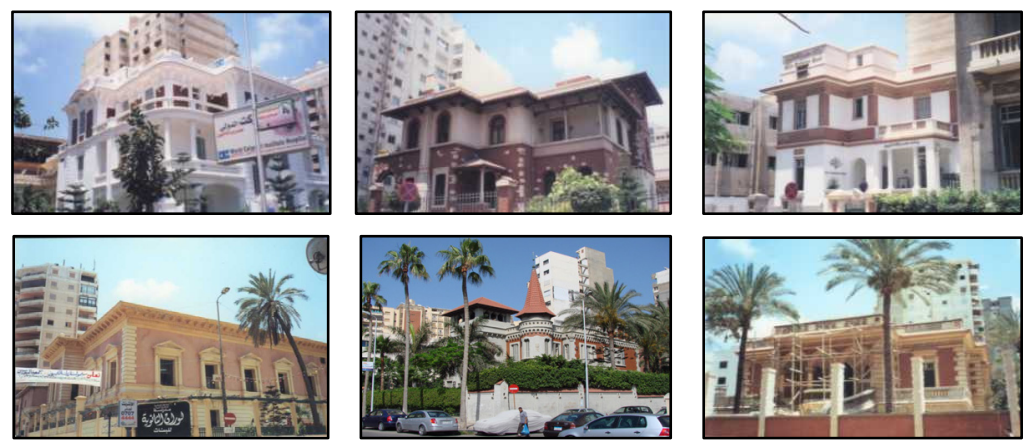

Figure 5: Examples of unique villas in Alexandria successfully re-used as branches of banks, schools, and clinics.

It is important models in processes preserve heritage buildings, re-use of these buildings owned by the state in some cultural, Historical and artistic purposes, Among the most important examples Palace of Princess Fatima Al-Zahra which was built in 1923 at Al-Ramleh district, where it became in 1986 the Museum of the Jewels of the Former Royal Family in Egypt (fig. 6).

On the other hand, increasing the public awareness by explaining to the public the importance of such buildings and their value of such heritage. In addition, this should be applied to the younger generation, by adding these concepts and information to their educational programs, to enable them to realize the importance of preserving this heritage.

As an example, the significance of this concept is shown in the incident of the American Consulate General in Alexandria. The Consulate was the proprietor of 

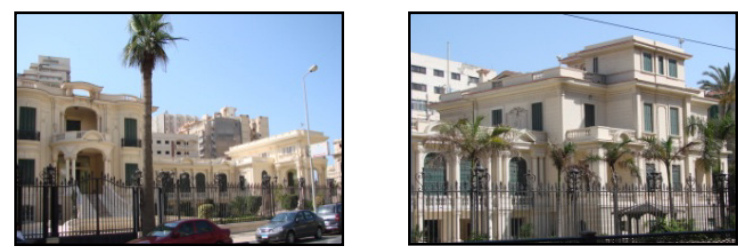

Figure 6: Museum of the Jewels of the Former Royal Family.

the palace it occupied for decades, the magnificent (Bassili Palace) located in AlHorreya Ave., and when it was decided to close the Consulate by the end of the 20th century, it was offered for sale. An entrepreneur offered to purchase the palace for LE 22 million (around 4 million \$), who was planning to demolish the palace and building a residential building in its place. However, as soon as the Egyptian Ministry of Culture offered to buy the palace to use it as the national museum for the history of Alexandria, the American Consulate accepted this offer, although the offer was only for LE 12 million (around 2 million \$) [10]. The Consulate has accepted a far less price for the only reason that the palace will be re-used for some noble objective and at the same time will preserve one rare building that bears the characteristics of a unique human creation that belongs to the refined architecture. The incident does not need more comments, but it might serve as a message "to whom it may concern" (fig. 7).

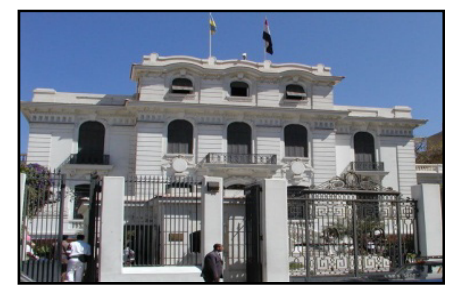

Figure 7: The national museum of Alexandria, as a successful example for preservation of architectural heritage.

\section{The major results and recommendations concerning preservation of Alexandria's architectural heritage}

1- It is important to give more concern for increasing the public cultural awareness of the heritage importance, as this would surely form an effective public opinion to confront the overwhelming materialistic tendencies and attitudes prevailing these days.

2- It is also important to fight the lack of firmness and decisiveness in applying laws and regulations that help to preserve these treasures, instead of issuing new legislation, since slackness and lenience make laws lose all their power. 
3- A search has to be conducted to look for an unconventional method to motivate economic establishments and large companies to sponsor the process of supporting and preserving heritage, through appropriate legislations.

4- Studying the experience of Alexandria comprehensive planning project, and reviving that part of the project on preserving this unique heritage, disregarding the groups fighting this action, and their opposing pressure force (Zahran [6]).

5- Studying the idea of approaching international cultural organizations and societies, to assist the governments in saving this heritage, such as the UNESCO and other organizations, since the government cannot possibly provide the highly expensive cost of this process.

6- Amending the current Monuments Protection Law in some countries like Egypt, to include those rare buildings as well, regardless of the clause that specifies recording a building as registered and legally protected monument only apply to buildings of minimum 100 years old, and to satisfy with only a decision to be taken by a high-level technical committee in this respect.

\section{Conclusions}

Alexandria has a distinct architectural heritage belongs to the nineteenth and twentieth centuries, which has been destroyed during the last years as a result of many reasons, particularly the lack of cultural awareness, weak of laws and the reluctance of officials and others. Therefore, many efforts must be provide official and popular, even from the relevant international institutions to assist in preserving this unique human heritage by all possible and available methods.

\section{References}

[1] Al-Rafey, A., History of the Nationalistic Movement, Period of Mohamed Aly, Dar Al-Maaref: Cairo, 1982.

[2] Awad, M., Italy in Alexandria, Influences on the Built Environment, Alexandria Preservation Trust: Alexandria, 2008.

[3] Shalaby, H. A., Chapters from the Modernization History of the Egyptian Cities (1820 -1914), General Egyptian Book Authority: Cairo, 1988.

[4] Heba, K. M., Urban Restoration to Egyptian Cities, Case study for Alexandria, Al-Azhar University Engineering Journal, Vol. 4, issue 2: Cairo, pp. 95-109, 2001.

[5] Heba, K. M., Heritage of Alexandria, Tasmeem periodical, issue 3: Cairo, pp.56-57, 2002.

[6] Zahran, M.M., The final Report of Alexandria Comprehensive PlanningAlexandria 2005, Heritage Conservation, Alexandria Governorate and Alexandria University: Alexandria, pp. 161-174, 1984.

[7] Haidar, F. A. Planning of Cities and Villages, Al-Maaref Establishment: Alexandria, pp. 484-503, 1994.

[8] Rezk, H., Massacre of Palaces and Villas in Alexandria, Al-Mosawer periodical, issue No. 3838: Cairo, pp.61-66, May 1998. 
[9] Architectural Heritage of Cairo and Paris, Al- Helal periodical, Issue 6, Year 110: Cairo, June 2002.

[10] The National Museum for the History of Alexandria, The official Web Site of Alexandria's governorate, www.alex4all.com/aboutAlex/articl.php?id $=39$ 